medRxiv preprint doi: https://doi.org/10.1101/2020.11.11.20229377; this version posted December 19, 2020. The copyright holder for this preprint (which was not certified by peer review) is the author/funder, who has granted medRxiv a license to display the preprint in perpetuity.

\title{
1 Early medical abortion using telemedicine - acceptability to patients
}

2

3

$4 \quad$ Name: Chelsey Porter Erlank

5 Institutional affiliation: Evidence to Action Department, MSI Reproductive Choices, London, UK

6 Postal address: MSI, 1 Conway Street, London, W1T 6LP

$7 \quad$ Email: chelsey.porter@MSIChoices.org

3 Orcid ID - https://orcid.org/0000-0001-7588-0565

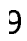

J Name: Dr Jonathan Lord*

1 Institutional affiliation: Medical Director, MSI Reproductive Choices, London, UK

2 Email: jonathan.lord@MSIChoices.org.uk

3 Orcid ID - https://orcid.org/0000-0003-2819-5973

Name: Dr Kathryn Church

6 Institutional affiliation: Evidence to Action Department, MSI Reproductive Choices, London, UK

$7 \quad$ Email: kathryn.church@MSIChoices.org

3 Orcid ID - https://orcid.org/0000-0003-4491-9521

$\exists$

* = Corresponding Author

1

2

Word count: 2475 
medRxiv preprint doi: https://doi.org/10.1101/2020.11.11.20229377; this version posted December 19, 2020. The copyright holder for this preprint (which was not certified by peer review) is the author/funder, who has granted medRxiv a license to display the preprint in perpetuity.

It is made available under a CC-BY-NC-ND 4.0 International license .
Early medical abortion using telemedicine - acceptability to patients

\section{MeSH / Keywords:}

3 Abortion, Induced [E04.520.050]

4 Telemedicine [N04.590.374.800]

5 Patient Reported Outcome Measures [E05.318.308.980.344.500]

5 Ambulatory Care Facilities [N02.278.035]

$7 \quad$ Health Planning [N03.349]

$3 \quad$ Mifepristone [D04.210.500.365.415.580]

$\exists \quad$ Misoprostol [D23.469.700.660.500]

\section{ABSTRACT}

4 Introduction

The English government approved both stages of early medical abortion (EMA) for at-home use on 30 ${ }^{\text {th }}$ March 2020. MSI Reproductive Choices UK (MSUK), one of the largest service providers of abortion services in England, launched a telemedicine EMA pathway on $6^{\text {th }}$ April 2020.

\section{Methods}

A sample of all MSUK's telemedicine EMA patients between April and August 2020 were invited to opt in to a follow-up call to answer clinical and satisfaction questions. 1,243 (13.7\% of all telemedicine EMAs) were successfully followedup, on average within five days post-procedure. Responses were analysed quantitatively and descriptively. The sample was compared to the total telemedicine EMA population on nine sets of background characteristics to check sample validity, and all results were tested across the same nine characteristics for variation.

\section{Results}

Patients reported high confidence in telemedicine EMA and high satisfaction with the convenience, privacy and ease of managing their abortion at home. No patient reported that they were unable to consult privately. Over $80 \%$ of patients reported preferring the telemedicine pathway, and two-thirds that they would choose telemedicine again if COVID-19 were no longer an issue.

\section{Discussion}

Telemedicine EMA is a valued, private, convenient and easier option that is highly acceptable for patients seeking an abortion, especially those for whom in-clinic visits are logistically or emotionally challenging. Evidence that this pathway would be a first choice again in future for most patients supports the case to make access to telemedicine EMA permanent.

\section{Key message points:}

- On $30^{\text {th }}$ March 2020, the English government approved both stages of early medical abortion (EMA) for at-home use, paving the way for telemedicine EMA provision. 
- MSUK patients receiving routine follow-up calls reported high confidence in telemedicine EMA and high satisfaction with the privacy, convenience and ease of this pathway.

- Two-thirds of telemedicine EMA patients reported they would choose this pathway again in future, demonstrating that it should remain available after the COVID-19 pandemic.

\section{INTRODUCTION}

Over the last twenty years medical methods of abortion have contributed an increasing share of total abortions in England and Wales, up to 73\% in 2019.(1) Guidelines from the UK's National Institute for Health and Care Excellence (NICE) state that women should be offered early medical abortion at home (EMA) up to 10 weeks gestation.(2) The process consists of two stages of medication (mifepristone and misoprostol), ideally taken 24-48 hours apart, with expulsion of pregnancy usually occurring at home. Until 2018 both stages of EMA had to be administered in a government approved clinic or hospital, despite evidence that this made access difficult for some patients (e.g. those in deprived and rural areas, those who have work and childcare commitments, and those who have stigma or privacy concerns).(3) From late 2018, government approved misoprostol for self-administration at home in England, but mifepristone still had to be administered in approved clinics/hospitals even though there is no medical rationale for this.(4)

After the UK went into national lockdown to manage the outbreak of COVID-19 in March 2020, professional bodies produced national guidelines that included the use of telemedicine to ensure abortion care could be continued safely in the pandemic. (5) On 30th March 2020 the English government announced temporary approval of home use of both stages of EMA, meaning that fully remote care using telemedicine could be implemented. (6)

MSI Reproductive Choices UK (MSUK), one of the main abortion care providers in the UK, rapidly developed a telemedicine EMA pathway that launched on $6^{\text {th }}$ April 2020.(7) In the new pathway, eligibility for EMA is assessed during the patient's initial call with a health advisor. Patients are screened using safeguarding and clinical eligibility questions based on national guidelines $(5,8)$ and they are booked for an in-depth telephone consultation with a nurse at which their choices are confirmed. If they can proceed and consent to telemedicine, patients are then given the choice to receive their EMA medication via the post or to pick it up with minimal contact from one of over 60 MSUK clinics across England. All MSUK patients, including those using the telemedicine EMA service, have access to support from a 24-hour aftercare line and comprehensive on line information.

This paper presents an analysis of post-procedure satisfaction data from telemedicine EMA patients to understand their experiences with this new pathway and their preferences for care.

\section{METHODS}

\section{Data collection}

At their consultation, telemedicine EMA patients were invited to opt-in to a follow-up call post-procedure with a care assistant (who had no other involvement in the patient's care). Due to pressure on resources during COVID-19, follow-up slots were limited and patients were invited until the daily allocation had been filled. During the follow-up call, patients were asked a set of multiple choice and open-ended questions about their service, and responses were captured in a secure digital database. Any patients expressing concerns during the call were offered a nurse call-back; $16.3 \%$ requested this.

As a service evaluation process, ethical approval was not sought for this analysis, but patients were informed of potential uses of their anonymous data processing for research or public interest, and participation was entirely voluntary. 
medRxiv preprint doi: https://doi.org/10.1101/2020.11.11.20229377; this version posted December 19, 2020. The copyright holder for this preprint (which was not certified by peer review) is the author/funder, who has granted medRxiv a license to display the preprint in perpetuity.

$6 \quad$ Feedback data were merged with nine medical and demographic background characteristic variables from an

7 anonymised clinical dataset using unique patient IDs, and all data cleaned in STATA-16 in preparation for analysis.

3 Descriptive analysis investigated patient perspectives in categories as detailed below. Comments from free-text fields

$\exists \quad$ were analysed to understand patient responses.

1 Outcomes and analysis

2 Overall, 9,049 unique patients received telemedicine EMA from MSUK between $6^{\text {th }}$ April and $31^{\text {st }}$ August 2020.

3 Telemedicine EMA services accounted for $44.0 \%$ of all medical abortions MSUK provided in this period. 2,704 (29.9\%)

4 were booked a follow-up call in this period and 1,243 (13.7\%) calls were completed. On average, eight days elapsed

5 between the patient's initial telemedicine EMA consultation and their follow-up call. Allowing at least 72 hours for

5 receipt and use of medication, this means that, on average, patients were followed-up within five days of the second

7 stage of EMA.

3

Э Sample validity

J Due to the opt-in nature of the follow-up calls and high non-response rate (54.0\%) among those who opted-in, the

1 follow-up sample may not be representative of MSUK's total population receiving telemedicine EMA during this

2 period. To understand the magnitude of possible sampling bias, patient profiles between the follow-up sample and

3 the overall telemedicine EMA population were compared using equality-of-proportion tests (Table 1).

4 The sample did not differ from the population by more than $\pm 5 \%$ on any background characteristic, except in three

5 criteria: patients from the South East region and patients picking up telemedicine medication were underrepresented

$6 \quad$ in the sample, while patients receiving medication via post were overrepresented.

7 To understand the impact of possible sampling bias on results, all results were disaggregated by the same nine

3 background characteristic groups and tested for significance using chi-squared tests or t-tests, with all differences

$\rightarrow$ reported in detail in the supplementary data table; significant differences are discussed in the text.

Patient and public involvement

\section{J Quality of consultation}

\section{RESULTS}

MSUK's telemedicine EMA model was launched rapidly to maintain essential access to abortion care during COVID-19 pandemic restrictions, leaving insufficient time for patient consultation on the collection of feedback data.

Table 2 presents all quantitative results. Table 3 includes extracts from free text responses. The supplementary data table provide details from the subgroup analysis.

During consultation, $95.3 \%$ of patients felt able to talk privately without problems but $4.6 \%$ had to act in order to talk privately (e.g. to get childcare, go to the car). No patients reported that they were unable to talk privately. This did not vary by subgroup except that patients aged 25-29 and 35-39, or with previous live births or miscarriage, were all more likely to report having to take action to talk privately.

Almost all (99.3\%) felt they had the opportunity to ask questions during their consultation, and this did not vary by subgroup. No free text comments indicated any external pressure/coercion during consultations. Many patients preferred having the consultation over the phone as it removed the stress of visiting a clinic and fear of judgement. 


\section{Accessing medication}

Almost one third (31.5\%) of telemedicine EMA patients chose to pick-up their medication from clinic, $68.1 \%$ chose postal. Of those receiving medications by post, the majority (88.2\%) said they had no concerns about doing so, and this did not differ significantly by any subgroup.

Most patients choosing post said they chose this option because it was easier, more private and more convenient with work, childcare and family life, because they lived too far from an MSUK clinic, or they did not drive. Over a quarter (26.7\%) chose post due to COVID-19 and $2.8 \%$ explicitly mentioned self-isolating or shielding at the time of their EMA.

Of those picking up medication from a clinic, most chose this because they wanted or needed to start the process more quickly, because they lived near a clinic so it was convenient, and/or because they had privacy or logistical concerns about receiving the medications via post, such as other members of the household intercepting the package, concerns about postal delays with COVID-19 or the medication going to an address they were not currently living at.

92.4\% reported they "definitely" had enough information to take the medications by themselves and $5.5 \%$ reported "somewhat". This did not differ by subgroup except patients aged under 20 and aged 35-39 were more likely to say confidently that they "definitely" had enough information. Free-text comments among those who wanted more information show they specifically wanted information on dosage, method of ingestion and the level of pain and bleeding to expect, particularly with the misoprostol. Many were reassured after speaking with the nurse or using the aftercare line or website.

$87.4 \%$ had no concerns about the safety of taking the medication by themselves. This did not vary significantly by subgroup except that patients who had at least one previous live birth and patients who were White British/White other were less likely to report concerns. Of the $12.6 \%$ who did have concerns, free-text comments revealed this was mainly general anxiety around EMA - if it would work, what level of bleeding and pain to expect, and how they would cope if they experienced complications - with concerns often alleviated through aftercare support.

Most reported being able to manage pain either "effectively" (87.9\%) or "somewhat effectively" (8.3\%) during their EMA. This did not differ by subgroup except that patients who had never had an abortion or live birth before were more likely to report managing only "somewhat effectively".

$86 \%$ felt confident they had passed the pregnancy, $11.4 \%$ were not sure and $3.0 \%$ said they were not confident. This did not differ by subgroup except patients aged $40+$ were less likely to feel confident they had passed the pregnancy. Those who were not confident or not sure were on average more likely to report little or no bleeding (18.3\% compared to $2.4 \%$ among those who were confident, $p<0.001$ ) and lower pain scores (5.7 pain score out of 10 among those who were not confident or unsure, compared to 6.2 among those who were confident, $p=0.006)$. Less confident patients were more likely to request a nurse call-back compared to those who were confident $(43.0 \%$ versus $12 \%, p<0.001)$.

\section{Overall satisfaction and perspectives on telemedicine EMA}

Overall, $98.2 \%$ rated their experience good/very good and only 7 patients $(0.6 \%)$ reported their experience as poor/very poor. Overall, this did not differ by subgroup except age group, where patients aged 25-29 and 30-34 years were marginally less likely to report a good/very good experience $(97.6 \%$ versus $99.7 \%$ average for other age groups, $p=0.005)$.

There was some variation between subgroups in rating the experience "very good" compared to all other responses, for example: patients aged under 20 and 25-29, patients with Black/African/Caribbean/Black British and Asian/Asian British ethnicity, and those from Greater London were all slightly less likely to report their experience as "very good" compared to other groups (Table 4). 
It js made available under a CC-BY-NC-ND 4.0 International license sure. This did not differ between subgroups, except among those who were Black/African/Caribbean/Black British or had unknown ethnicity - these were more likely to report they would have preferred a face-to-face pathway, or that they were not sure. The patients who would have preferred face-to-face care mainly cited a desire for the emotional and practical reassurance of an interpersonal interaction.

When asked about future abortion preferences post-COVID-19, 22.1\% would prefer face-to-face care, again mainly for personal contact and reassurance. Those voicing preference for face-to-face care for their current abortion were also more likely to report wanting face-to-face care in the future. $11.6 \%$ were unsure on future choice, saying it would be dependent on circumstances (such as gestational age or living arrangements) or that they wanted to avoid another abortion. This did not differ by subgroups, except age, where patients under 20 were much less likely to respond "I don't know/it depends" and more likely to decisively report wanting a face-to-face abortion in the future, versus other age groups.

Two-thirds of patients $(66.3 \%)$ reported a preference for a future telemedicine EMA if there were no COVID-19 restrictions ( $61.4 \%$ by phone, $4.9 \%$ by video link), describing it as more comfortable, private, convenient, quicker and easier.

Hundreds of free-text comments revealed just how much patients valued having the option to complete their abortion in their own homes and on their own terms, and how much easier it was to talk freely when not face-to-face (Table 3 ).

\section{DISCUSSION}

Prior to the pandemic, telemedicine had already been recommended by national guidelines to improve access to abortion care,(2) but during COVID-19 it has been essential to maintain services whilst minimising viral transmission. Telemedicine EMA has overcome many of the barriers associated with in-clinic abortion care(3) and has provided a valued option for tens of thousands of women to manage their abortion in their own homes and on their own terms.(9) It improves access to abortion care, and is especially useful for those who juggle work and childcare responsibilities, have privacy concerns, who live far from clinics or are otherwise vulnerable.(2) Patients in this followup sample reported confidence in the telemedicine EMA process and had high levels of satisfaction with the convenience, privacy and ease of being able to complete their abortion at-home. Our findings echo those from earlier, smaller studies that telemedicine is acceptable to most women.(10-14)

It is particularly reassuring that not only were no significant privacy or coercion concerns reported at all, but many highlighted that telemedicine offered them greater privacy than having to attend clinic.

Telemedicine is not a panacea, with a fifth of patients indicating they would like any care in the future to include at least some face-to-face interaction. These differences may reflect specific concerns about aspects of the EMA process, or could simply indicate that some demographic groups were more likely to prefer the reassurance of a faceto-face interaction. The findings indicate the need to maintain face-to-face abortion care as a choice for patients, since not all are eligible for or would choose a telemedicine consultation. It is also important to ensure that access to after-care and support is readily available.

This study has limitations. On the positive side, the survey was administered within an average five days of the abortion, among a population who were easily identifiable and whose recollection is likely to be good. The sample size achieved was large relative to most post-service surveys. However the approach has weaknesses. MSUK nurses recruited the follow-up sample, introducing the possibility of selection bias. MSUK care assistants collected follow-up data, with potential for courtesy bias, although this was mitigated by care assistants not being involved in other parts of patient care and following a pre-defined script.

6 It is reassuring that the patient profiles in the sample and whole population were reasonably well-matched.

7 Similarities on demographics and medical history between the sample and total population (and overall relative 
medRxiv preprint doi: https://doi.org/10.1101/2020.11.11.20229377; this version posted December 19, 2020. The copyright holder for this preprint (which was not certified by peer review) is the author/funder, who has granted medRxiv a license to display the preprint in perpetuity.

3 consistency of results between sub-groups, particularly between postal and pick-up patients) offers reassurance that

$\exists$ significant selection bias has been minimised. However there were some significant differences between the sample

$\jmath$ and population and it is unknown whether these could have influenced results to under-or over-represent overall

1 satisfaction.

2 Overall, while the option of in-person care should continue to be freely available for the minority who need or prefer it 3 for reassurance and support, telemedicine EMA is a valued, private, convenient and easier option for most patients 4 seeking an abortion. This study shows that, even without COVID-19 restrictions, telemedicine EMA would still be 5 many patients' first choice of pathway, and this finding (coupled with parallel findings on telemedicine safety and 6 effectiveness, [personal communication: Aiken, Lohr \& Lord 2020]) makes the argument for continuing to offer this 7 service after the COVID-19 pandemic compelling.

\section{Э ACKNOWLEDGEMENTS}

$J$ We would like to thank Cat James and her team for their help in organising and conducting the survey. We would also 1 like to thank Kay Newey and Abigail Storan for project planning and delivery, all the nurses who contributed and of 2 course the patients who kindly gave their time to participate. 
medRxiv preprint doi: https://doi.org/10.1101/2020.11.11.20229377; this version posted December 19, 2020. The copyright holder for this preprint (which was not certified by peer review) is the author/funder, who has granted medRxiv a license to display the preprint in perpetuity.

5 Table 1: Equality of proportions test between the follow-up sample and total telemedicine EMA population

\begin{tabular}{|c|c|c|c|c|}
\hline & $\begin{array}{l}\text { \% telemedicine EMA } \\
\text { population April- } \\
\text { August } 2020 \text { ( } N=9,049)\end{array}$ & $\begin{array}{l}\text { \% telemedicine EMA } \\
\text { follow-up sample } \\
\text { April-August } 2020 \\
(N=1,243)\end{array}$ & 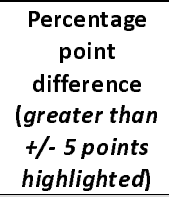 & $\begin{array}{c}\text { Equality of proportions } \\
\text { test } p \text {-value } \\
\text { (*significant } p<0.05 \\
\text { **very significant } \\
\text { p<0.01) }\end{array}$ \\
\hline \multicolumn{5}{|l|}{ Age groups } \\
\hline Under 20s & $6.8 \%$ & $5.4 \%$ & -1.4 & $p=0.024^{*}$ \\
\hline Aged 20-29 & $44.3 \%$ & $41.2 \%$ & -3.1 & $\mathrm{p}=0.014^{*}$ \\
\hline Aged 30-39 & $40.7 \%$ & $41.5 \%$ & +0.8 & $\mathrm{P}=0.268$ \\
\hline Aged 40+ & $8.0 \%$ & $9.7 \%$ & +1.7 & $\mathrm{p}=0.011^{*}$ \\
\hline Unknown age & $0.3 \%$ & $2.2 \%$ & +1.9 & $p<0.001^{* *}$ \\
\hline \multicolumn{5}{|l|}{ Ethnicity } \\
\hline White British/White other & $66.0 \%$ & $63.3 \%$ & -2.7 & $\mathrm{p}=0.025^{*}$ \\
\hline Mixed/Multiple ethnicities & $5.0 \%$ & $5.6 \%$ & +0.6 & $\mathrm{p}=0.191$ \\
\hline Black/African/Caribbean/Black British & $10.5 \%$ & $12.7 \%$ & +2.2 & $\mathrm{p}=0.006^{* *}$ \\
\hline Asian/Asian British & $8.1 \%$ & $7.5 \%$ & -0.6 & $\mathrm{p}=0.212$ \\
\hline Other ethnic group (not specified) & $1.8 \%$ & $2.1 \%$ & +0.3 & $\mathrm{p}=0.246$ \\
\hline Unknown ethnicity & $8.6 \%$ & $8.9 \%$ & +0.3 & $\mathrm{P}=0.382$ \\
\hline \multicolumn{5}{|l|}{ Marital status } \\
\hline Single & $32.8 \%$ & $31.1 \%$ & -1.7 & $\mathrm{p}=0.102$ \\
\hline Partnered & $35.1 \%$ & $33.4 \%$ & -1.7 & $\mathrm{p}=0.100$ \\
\hline Married/Civil partnership & $17.8 \%$ & $19.5 \%$ & +1.7 & $\mathrm{p}=0.067$ \\
\hline Separated/Widowed/Divorced & $2.5 \%$ & $3.2 \%$ & +0.7 & $\mathrm{p}=0.058$ \\
\hline Unknown marital status & $11.7 \%$ & $12.8 \%$ & +1.1 & $\mathrm{p}=0.113$ \\
\hline \multicolumn{5}{|l|}{ Home region } \\
\hline East England & $0.03 \%$ & $0.0 \%$ & -0.0 & $\mathrm{p}=0.271$ \\
\hline East Midlands & $0.5 \%$ & $0.3 \%$ & -0.2 & $\mathrm{p}=0.176$ \\
\hline East of England & $11.1 \%$ & $15.6 \%$ & +4.5 & $\mathrm{p}<0.001^{* *}$ \\
\hline Greater London & $46.4 \%$ & $50.3 \%$ & +3.9 & $\mathrm{p}=0.003 * *$ \\
\hline North East & $6.4 \%$ & $3.1 \%$ & -3.4 & $\mathrm{p}<0.001^{* *}$ \\
\hline North West & $17.5 \%$ & $16.5 \%$ & -1.0 & $\mathrm{p}=0.182$ \\
\hline South East & $10.7 \%$ & $5.4 \%$ & -5.3 & $\mathrm{p}<0.001^{* *}$ \\
\hline South West & $6.2 \%$ & $6.1 \%$ & -0.8 & $\mathrm{p}=0.456$ \\
\hline West Midlands & $0.9 \%$ & $0.6 \%$ & -0.3 & $\mathrm{p}=0.135$ \\
\hline Region unknown & $0.3 \%$ & $2.2 \%$ & +1.9 & $\mathrm{p}<0.001^{* *}$ \\
\hline \multicolumn{5}{|l|}{ Postal vs pick-up } \\
\hline Postal only & $59.5 \%$ & $65.6 \%$ & +6.2 & $p<0.001 * *$ \\
\hline Pick up only & $38.4 \%$ & $30.6 \%$ & -7.8 & $p<0.001^{* *}$ \\
\hline Unknown or combination (i.e. repeats) & $2.1 \%$ & $3.8 \%$ & +0.1 & $\mathrm{p}<0.001^{* *}$ \\
\hline \multicolumn{5}{|l|}{ Previous abortions } \\
\hline At least one previous abortion & $48.4 \%$ & $48.2 \%$ & -0.2 & $\mathrm{p}=0.441$ \\
\hline \multicolumn{5}{|l|}{ Previous live births } \\
\hline At least one previous live birth & $62.5 \%$ & $65.1 \%$ & +2.6 & $\mathrm{p}=0.029^{*}$ \\
\hline \multicolumn{5}{|l|}{ Previous miscarriage } \\
\hline At least one previous miscarriage & $22.4 \%$ & $24.4 \%$ & +2.0 & $\mathrm{p}=0.047^{*}$ \\
\hline \multicolumn{5}{|l|}{ Previous caesarean section } \\
\hline At least one previous caesarean section & $15.1 \%$ & $16.8 \%$ & +1.7 & $\mathrm{p}=0.043^{*}$ \\
\hline Total & $9,049(100 \%)$ & $1,243(100 \%)$ & & \\
\hline
\end{tabular}

3 Table 2: Descriptive results of key outcomes

\begin{tabular}{|c|c|c|c|}
\hline \multirow{6}{*}{$\begin{array}{l}\text { Quality of } \\
\text { consultation }\end{array}$} & \multicolumn{3}{|c|}{ N (\%) of sample reporting ability to talk privately during consultation } \\
\hline & Yes definitely - I could talk privately & $\begin{array}{c}\text { Yes somewhat - but I had to take } \\
\text { action }\end{array}$ & Not sure - I had to be careful \\
\hline & $1185(95.3 \%)$ & $57(4.6 \%)$ & $1(0.1 \%)$ \\
\hline & \multicolumn{3}{|c|}{$\mathrm{N}(\%)$ sa mple reporting opportunity to ask questions during consultation } \\
\hline & \multicolumn{2}{|c|}{ Yes - had opportunity to ask questions } & No opportunity to ask questions \\
\hline & \multicolumn{2}{|l|}{$1234(99.3 \%)$} & $\begin{array}{l}\text { unity to ask questions } \\
9(0.7 \%)\end{array}$ \\
\hline
\end{tabular}


medRxiv preprint doi: https://doi.org/10.1101/2020.11.11.20229377; this version posted December 19, 2020. The copyright holder for this preprint (which was not certified by peer review) is the author/funder, who has granted medRxiv a license to display the preprint in perpetuity.

\begin{tabular}{|c|c|c|c|c|}
\hline \multirow{6}{*}{$\begin{array}{l}\text { Accessing } \\
\text { medication }\end{array}$} & \multicolumn{4}{|c|}{$\begin{array}{l}\text { It is made available under a CC-BY-NC-ND } 4.0 \text { International license } \\
\mathbf{N}(\%) \text { sample reporting receiving their medications by post or pick-up from a clinic }\end{array}$} \\
\hline & Postal & Pick-up & \multicolumn{2}{|c|}{ Unknown or combination } \\
\hline & $846(68.1 \%)$ & $391(31.5 \%)$ & \multicolumn{2}{|c|}{$6(0.5 \%)$} \\
\hline & \multicolumn{4}{|c|}{ n (\%) postal sample reporting concerns about receiving medications by post } \\
\hline & Yes, had concerns & No concerns & \multicolumn{2}{|c|}{ Missing response } \\
\hline & $71(8.4 \%)$ & $746(88.2 \%)$ & \multicolumn{2}{|c|}{$29(3.4 \%)$} \\
\hline \multirow{12}{*}{$\begin{array}{c}\text { Managing the } \\
\text { process at home }\end{array}$} & \multicolumn{4}{|c|}{$\mathrm{N}(\%)$ sample reporting they had enough information to take the medications themselves } \\
\hline & Yes definitely & Yes somewhat & \multicolumn{2}{|c|}{ No - not enough info } \\
\hline & $1148(92.4 \%)$ & $68(5.5 \%)$ & \multicolumn{2}{|c|}{$27(2.2 \%)$} \\
\hline & \multicolumn{4}{|c|}{$\mathrm{N}(\%)$ sample reporting concerns about the safety of taking medications themselves } \\
\hline & \multicolumn{2}{|c|}{ Yes, had concerns } & \multicolumn{2}{|l|}{ No concerns } \\
\hline & \multicolumn{2}{|c|}{$157(12.6 \%)$} & \multicolumn{2}{|l|}{$1086(87.4 \%)$} \\
\hline & \multicolumn{4}{|c|}{$\mathrm{N}(\%)$ sample reporting being able to manage their pain during EMA effectively } \\
\hline & Yes, managed effectively & Yes, somewhat effectively & Not sure & $\begin{array}{l}\text { Did not manage } \\
\text { effectively }\end{array}$ \\
\hline & $1093(87.9 \%)$ & $103(8.3 \%)$ & $4(0.3 \%)$ & $43(3.5 \%)$ \\
\hline & \multicolumn{4}{|c|}{$\mathrm{N}(\%)$ sample reporting confidence they had passed the pregnancy } \\
\hline & Yes, confident & Not sure & \multicolumn{2}{|c|}{ No - not confident } \\
\hline & $1064(85.6 \%)$ & $142(11.4 \%)$ & \multicolumn{2}{|c|}{$37(3.0 \%)$} \\
\hline
\end{tabular}

\begin{tabular}{|c|c|c|c|c|c|c|}
\hline \multirow{9}{*}{$\begin{array}{l}\text { Overall satisfaction } \\
\text { \& preferences }\end{array}$} & \multicolumn{6}{|c|}{$\mathrm{N}(\%)$ sample rating their experience of telemedicine EMA } \\
\hline & Very good & Good & $\begin{array}{l}\text { Neither good } \\
\text { nor poor }\end{array}$ & Poor & Very poor & Don't know \\
\hline & $1047(84.2 \%)$ & $173(13.9 \%)$ & $10(0.8 \%)$ & $5(0.4 \%)$ & $2(0.2 \%)$ & $6(0.5 \%)$ \\
\hline & \multicolumn{6}{|c|}{$\mathrm{N}(\%)$ sample reporting they would have preferred face-to-face care for this abortion } \\
\hline & \multicolumn{2}{|c|}{ Would have preferred face-to-face } & \multicolumn{2}{|c|}{$\begin{array}{l}\text { Would not have preferred face-to- } \\
\text { face }\end{array}$} & \multicolumn{2}{|c|}{ Not sure } \\
\hline & \multicolumn{2}{|c|}{$201(16.2 \%)$} & \multicolumn{2}{|c|}{$1035(83.3 \%)$} & \multicolumn{2}{|c|}{$7(0.6 \%)$} \\
\hline & \multicolumn{6}{|c|}{$\mathrm{N}(\%)$ sample reporting their preference for abortion care pathways in the future } \\
\hline & \multicolumn{2}{|c|}{ Would prefer face-to-face in future } & \multicolumn{2}{|c|}{ Would prefer telephone in future } & $\begin{array}{l}\text { Would prefer } \\
\text { video link in } \\
\text { future }\end{array}$ & $\begin{array}{l}\text { Don't know/ it } \\
\text { depends }\end{array}$ \\
\hline & \multicolumn{2}{|c|}{$275(22.1 \%)$} & \multicolumn{2}{|c|}{$763(61.4 \%)$} & $61(4.9 \%)$ & $144(11.6 \%)$ \\
\hline
\end{tabular}

1 Table 3: Extracts from Free Text Responses

\section{Quality of consultation}

"...easier to speak over the phone, and [they] did not feel judged"

"By phone is more convenient and more relaxed, [abortion] is a decision that isn't easy and an inclinic appointment may make the situation feel worse"

\section{Accessing medication}

"Client is [a] single mum and with current situation with COVID-19, [it was] more convenient and safer to take medicine at home"

"Client was isolating at the time of treatment - but if she wasn't isolating, she [still] would have taken postal because of [the] privacy at home"

"[Client] didn't want to wait longer for post to come, [they] wanted to do complete treatment before

Early medical abortion using telemedicine - acceptability to patients 
medRxiv preprint doi: https://doi.org/10.1101/2020.11.11.20229377; this version posted December 19 , 2020. The copyright holder for this preprint (which was not certified by peer review) is the author/funder, who has granted medRxiv a license to display the preprint in perpetuity.

going back to work"

It is made available under a CC-BY-NC-ND 4.0 International lieense.

"Client lives near the clinic and thought it would be quicker"

"[Client is] at uni. [and] didn't want [the medication] to be sent to [their] home address"

\section{Managing the process at home}

"Client found instructions a bit confusing but had support ... used video on MSI website about process to explain"

"Client was a bit confused about whether to take the final dose of misoprostol but called the nurse who explained the process"

"[Client] had concerns on bleeding - but then read information sheet and [was] reassured"

"[Client was] concerned about the amount of pain and what to expect - nurse gave advice about taking painkillers"

"[Client] was a bit apprehensive but felt more comfortable after nurse consultation - [re]assured about having 24/7 helpline"

\section{Overall satisfaction and perspectives on telemedicine EMA}

"Due to COVID-19 lockdown the telemedicine option was the best - [but] client would be more confident with [a] face-to-face interaction"

"This was [the client's] first pregnancy, it is reassuring to speak to someone over the phone, but faceto-face contact is more reassuring"

"[Client was] very happy with the service and treatment... really valued being able to have treatment in the comfort of her own home. Client stated she could cry-she is so happy!"

"[Client] really valued being able to take medications at home because had additional stress at work and felt the whole experience was made easier. Give women more choice."

"[Client felt it was] really nice to have that choice - [they felt that] as a woman we should have the right to make our own choices and it's harder to talk face-to-face than over the [phone]"

"After this experience, [the client] would choose this option again, private and comfortable in [her] own home. The nurse was very informative and reassuring"

"Everything was amazing, the support was amazing, [client said] "I hope this carries on [as] it helps people like me with children'. The 24 hour helpline was so helpful. From start to finish... it has been amazing."

4 Table 4. Subgroup testing for reporting the experience as "very good"

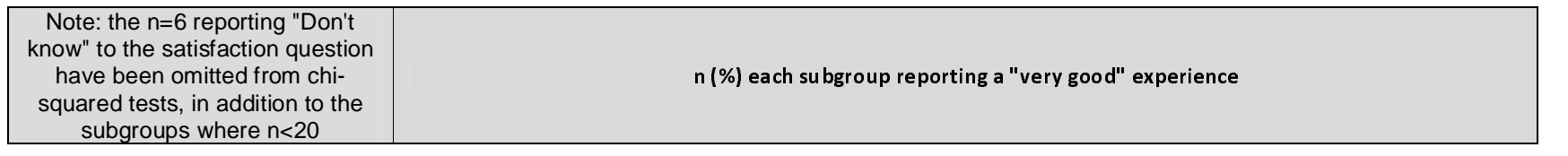


medRxiv preprint doi: https://doi.org/10.1101/2020.11.11.20229377; this version posted December 19, 2020. The copyright holder for this preprint (which was not certified by peer review) is the author/funder, who has granted medRxiv a license to display the preprint in perpetuity.

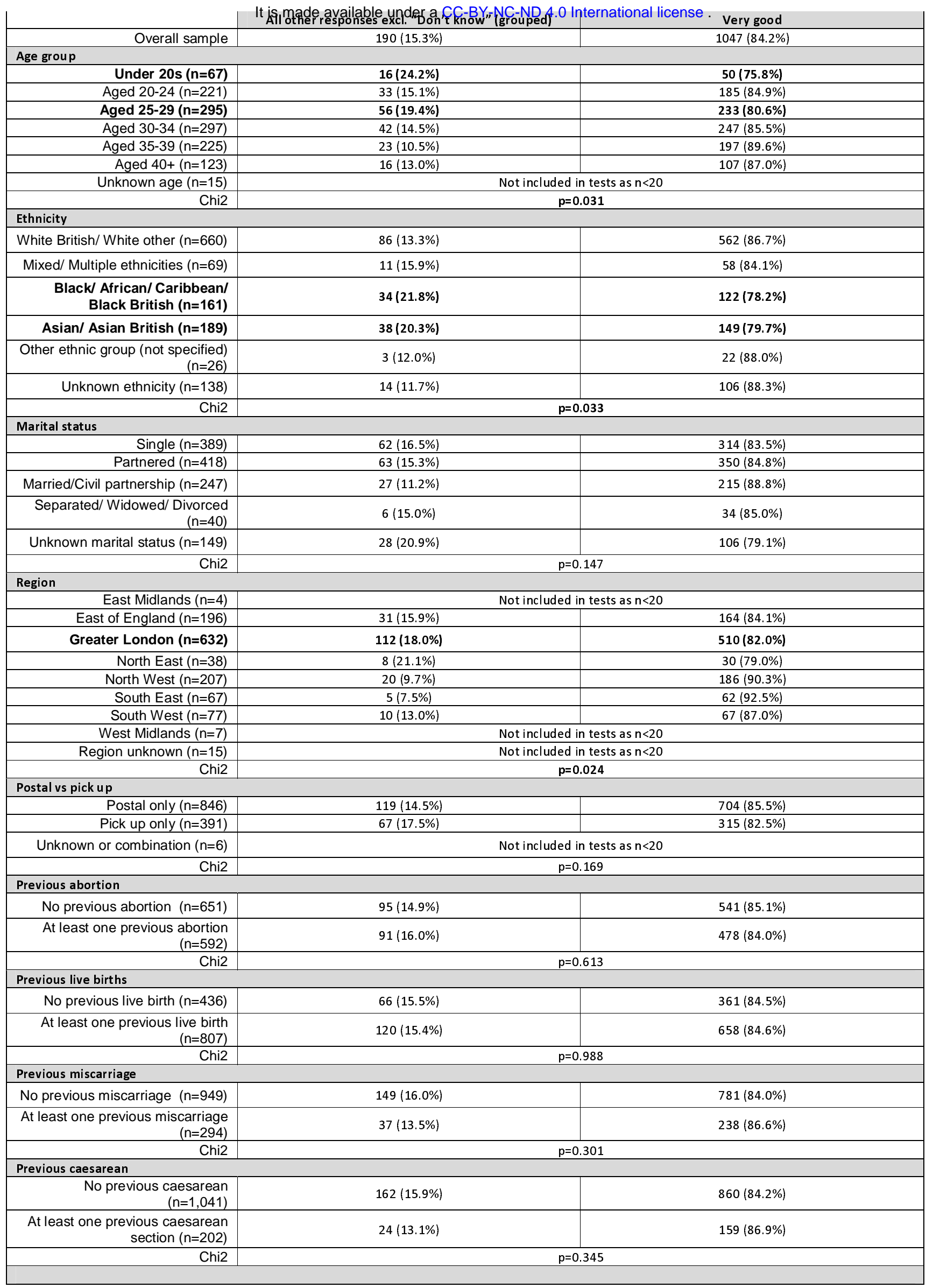




\section{SUPPLEMENTARY MATERIAL}

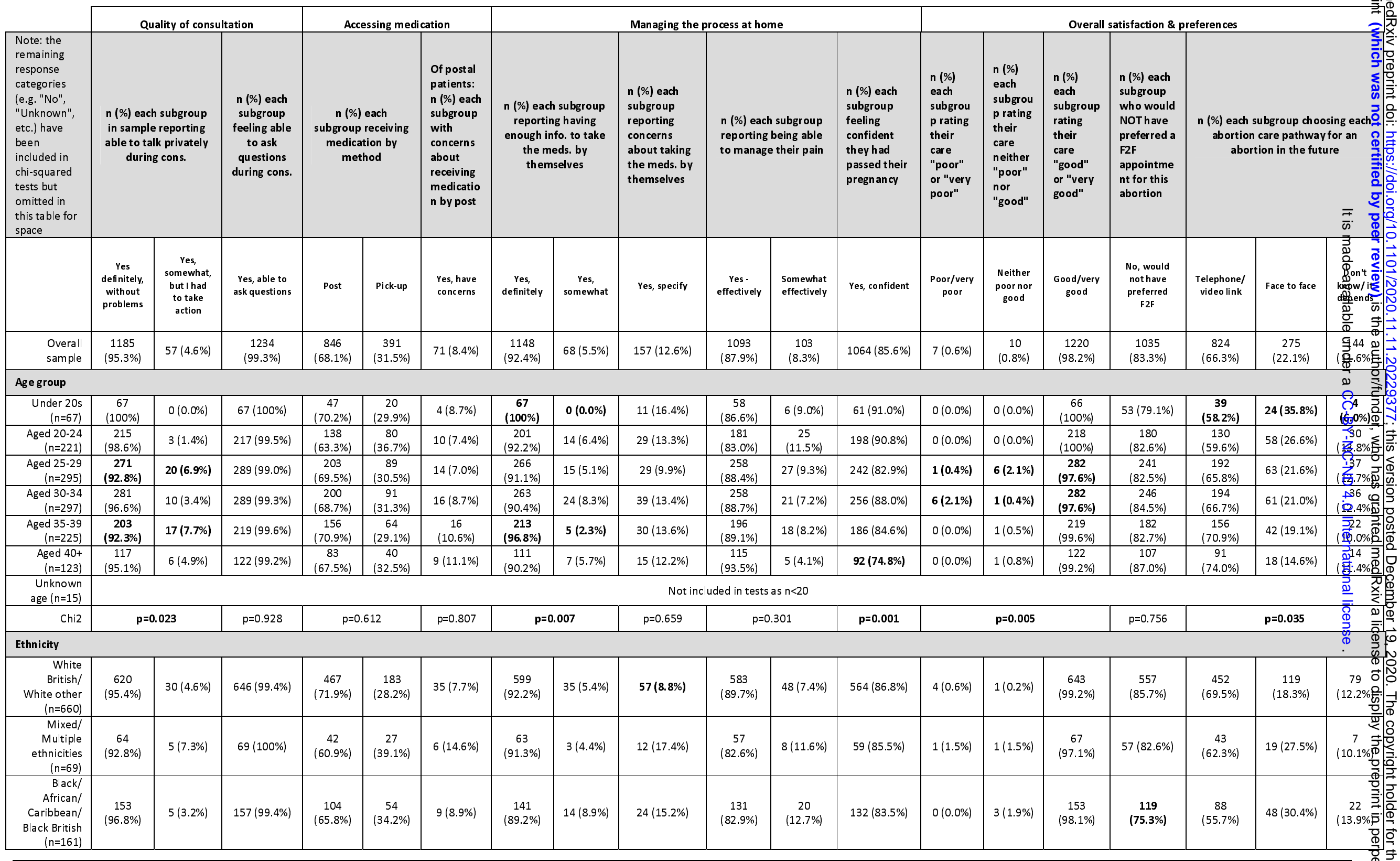




\begin{tabular}{|c|c|c|c|c|c|c|c|c|c|c|c|c|c|c|c|c|c|c|c|}
\hline $\begin{array}{r}\text { Asian/ Asian } \\
\text { British } \\
(n=189) \\
\end{array}$ & $\begin{array}{c}179 \\
(95.2 \%)\end{array}$ & $9(4.8 \%)$ & $186(98.9 \%)$ & $\begin{array}{c}117 \\
(62.2 \%)\end{array}$ & $\begin{array}{c}71 \\
(37.8 \%)\end{array}$ & $8(7.1 \%)$ & $\begin{array}{c}179 \\
(95.2 \%)\end{array}$ & $8(4.3 \%)$ & $30(16.0 \%)$ & $\begin{array}{c}165 \\
(87.8 \%)\end{array}$ & $17(9.0 \%)$ & $163(86.7 \%)$ & $1(0.5 \%)$ & $3(1.6 \%)$ & $\begin{array}{c}183 \\
(97.9 \%)\end{array}$ & $\begin{array}{c}161 \\
(85.6 \%)\end{array}$ & $\begin{array}{c}127 \\
(67.6 \%)\end{array}$ & $44(23.4 \%)$ & 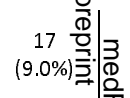 \\
\hline $\begin{array}{r}\text { Other ethnic } \\
\text { group (not } \\
\text { specified) } \\
(n=26)\end{array}$ & $\begin{array}{c}22 \\
(88.0 \%)\end{array}$ & $3(12.0 \%)$ & $25(100 \%)$ & $\begin{array}{c}17 \\
(68.0 \%)\end{array}$ & $\begin{array}{c}8 \\
(32.0 \%)\end{array}$ & $4(26.7 \%)$ & $\begin{array}{c}23 \\
(92.0 \%)\end{array}$ & $2(8.0 \%)$ & $5(20.0 \%)$ & $\begin{array}{c}25 \\
(100 \%)\end{array}$ & $0(0.0 \%)$ & $19(76.0 \%)$ & $0(0.0 \%)$ & $0(0.0 \%)$ & $\begin{array}{c}25 \\
(100 \%)\end{array}$ & $21(84.0 \%)$ & $\begin{array}{c}16 \\
(64.0 \%)\end{array}$ & $5(20.0 \%)$ & 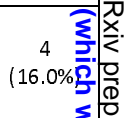 \\
\hline $\begin{array}{l}\text { Unknown } \\
\text { ethnicity } \\
(n=138) \\
\end{array}$ & $\begin{array}{c}116 \\
(95.9 \%)\end{array}$ & $4(3.3 \%)$ & $120(99.2 \%)$ & $\begin{array}{c}80 \\
(66.1 \%)\end{array}$ & $\begin{array}{c}41 \\
(33.9 \%)\end{array}$ & $7(9.1 \%)$ & $\begin{array}{c}116 \\
(95.9 \%)\end{array}$ & $3(2.5 \%)$ & $25(20.7 \%)$ & $\begin{array}{c}105 \\
(86.8 \%)\end{array}$ & $9(7.4 \%)$ & $98(81.0 \%)$ & $1(0.8 \%)$ & $1(0.8 \%)$ & $\begin{array}{c}118 \\
(98.3 \%)\end{array}$ & $94(77.7 \%)$ & $\begin{array}{c}76 \\
(62.8 \%)\end{array}$ & $31(25.6 \%)$ & 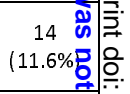 \\
\hline Chi2 & \multicolumn{2}{|c|}{$p=0.156$} & $\mathrm{p}=0.948$ & \multicolumn{2}{|c|}{$\mathrm{p}=0.093$} & $\mathrm{p}=0.115$ & \multicolumn{2}{|c|}{$\mathrm{p}=0.293$} & $p=0.001$ & \multicolumn{2}{|c|}{$\mathrm{p}=0.203$} & $\mathrm{p}=0.375$ & \multicolumn{3}{|c|}{$\mathrm{p}=0.390$} & $p=0.020$ & \multirow{2}{*}{\multicolumn{3}{|c|}{$p=0.063$}} \\
\hline \multicolumn{18}{|l|}{ Marital status } & & \\
\hline $\begin{array}{r}\text { Single } \\
(n=389)\end{array}$ & $\begin{array}{c}360 \\
(94.7 \%)\end{array}$ & $20(5.3 \%)$ & $378(99.5 \%)$ & \begin{tabular}{c|}
268 \\
$(70.5 \%)$
\end{tabular} & $\begin{array}{c}112 \\
(29.5 \%)\end{array}$ & $25(9.6 \%)$ & $\begin{array}{c}355 \\
(93.4 \%)\end{array}$ & $20(5.3 \%)$ & $45(11.8 \%)$ & $\begin{array}{c}325 \\
(85.5 \%)\end{array}$ & $\begin{array}{c}41 \\
(10.8 \%)\end{array}$ & $326(85.8 \%)$ & $1(0.3 \%)$ & $3(0.8 \%)$ & $\begin{array}{c}372 \\
(98.9 \%)\end{array}$ & $\begin{array}{c}312 \\
(82.1 \%)\end{array}$ & $\begin{array}{c}233 \\
(61.3 \%)\end{array}$ & $93(24.5 \%)$ & 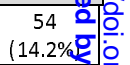 \\
\hline $\begin{array}{r}\text { Partnered } \\
(n=418)\end{array}$ & $\begin{array}{c}398 \\
(96.1 \%)\end{array}$ & $15(3.6 \%)$ & $412(99.5 \%)$ & $\begin{array}{c}273 \\
(65.9 \%)\end{array}$ & $\begin{array}{c}141 \\
(34.1 \%)\end{array}$ & $22(8.5 \%)$ & $\begin{array}{c}380 \\
(91.8 \%)\end{array}$ & $21(5.1 \%)$ & $59(14.3 \%)$ & $\begin{array}{c}357 \\
(86.2 \%)\end{array}$ & $38(9.2 \%)$ & $358(86.5 \%)$ & $1(0.2 \%)$ & $4(1.0 \%)$ & $\begin{array}{c}408 \\
(98.8 \%)\end{array}$ & $\begin{array}{c}342 \\
(82.6 \%)\end{array}$ & $\begin{array}{c}271 \\
(65.5 \%)\end{array}$ & $98(23.7 \%)$ & 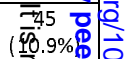 \\
\hline $\begin{array}{r}\text { Married/Civil } \\
\text { partnership } \\
(n=247)\end{array}$ & $\begin{array}{c}225 \\
(92.6 \%)\end{array}$ & $18(7.4 \%)$ & $241(99.2 \%)$ & $\begin{array}{c}164 \\
(67.5 \%)\end{array}$ & $\begin{array}{c}79 \\
(32.5 \%)\end{array}$ & $\begin{array}{c}17 \\
(10.7 \%)\end{array}$ & $\begin{array}{c}221 \\
(91.0 \%)\end{array}$ & $15(6.2 \%)$ & $30(12.4 \%)$ & $\begin{array}{c}228 \\
(93.8 \%)\end{array}$ & $9(3.7 \%)$ & $198(81.5 \%)$ & $3(1.2 \%)$ & $0(0.0 \%)$ & $\begin{array}{c}239 \\
(98.8 \%)\end{array}$ & $\begin{array}{c}207 \\
(85.2 \%)\end{array}$ & $\begin{array}{c}175 \\
(72.0 \%)\end{array}$ & $39(16.1 \%)$ & 苔. \\
\hline $\begin{array}{r}\text { Separated/ } \\
\text { Widowed/ } \\
\text { Divorced } \\
(n=40)\end{array}$ & $\begin{array}{c}40 \\
(100 \%)\end{array}$ & $0(0.0 \%)$ & $40(100 \%)$ & $\begin{array}{c}28 \\
(70.0 \%)\end{array}$ & $\begin{array}{c}12 \\
(30.0 \%)\end{array}$ & $2(7.1 \%)$ & $\begin{array}{c}39 \\
(97.5 \%)\end{array}$ & $1(2.5 \%)$ & $4(10.0 \%)$ & $\begin{array}{c}37 \\
(92.5 \%)\end{array}$ & $3(7.5 \%)$ & $32(80.0 \%)$ & $0(0.0 \%)$ & $0(0.0 \%)$ & $\begin{array}{c}40 \\
(100 \%)\end{array}$ & $36(90.0 \%)$ & $\begin{array}{c}28 \\
(70.0 \%)\end{array}$ & $9(22.5 \%)$ & 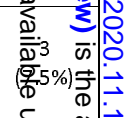 \\
\hline $\begin{array}{r}\text { Unknown } \\
\text { marital } \\
\text { status } \\
(n=149) \\
\end{array}$ & $\begin{array}{c}131 \\
(97.8 \%)\end{array}$ & $3(2.2 \%)$ & $132(98.5 \%)$ & $\begin{array}{c}94 \\
(70.2 \%)\end{array}$ & $\begin{array}{c}40 \\
(29.9 \%)\end{array}$ & $3(3.3 \%)$ & $\begin{array}{c}126 \\
(94.0 \%)\end{array}$ & $8(6.0 \%)$ & $15(11.2 \%)$ & $\begin{array}{c}119 \\
(88.8 \%)\end{array}$ & $11(8.2 \%)$ & $121(90.3 \%)$ & $2(1.5 \%)$ & $2(1.5 \%)$ & $\begin{array}{c}130 \\
(97.0 \%)\end{array}$ & $\begin{array}{c}112 \\
(83.6 \%)\end{array}$ & $\begin{array}{c}95 \\
(70.9 \%)\end{array}$ & $27(20.2 \%)$ & 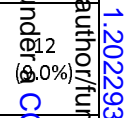 \\
\hline Chi2 & \multicolumn{2}{|c|}{$p=0.194$} & $\mathrm{p}=0.721$ & \multicolumn{2}{|c|}{$\mathrm{p}=0.686$} & $p=0.350$ & \multicolumn{2}{|c|}{$\mathrm{p}=0.337$} & $p=0.787$ & \multicolumn{2}{|c|}{$\mathrm{p}=0.073$} & $\mathrm{p}=0.138$ & \multicolumn{3}{|c|}{$p=0.355$} & $p=0.653$ & \multirow{2}{*}{\multicolumn{2}{|c|}{$\mathrm{p}=0.126$}} & W \\
\hline \multicolumn{17}{|l|}{ Region } & & & \\
\hline $\begin{array}{r}\text { East } \\
\text { Midlands } \\
(\mathrm{n}=4)\end{array}$ & \multicolumn{18}{|c|}{ Not included in tests as $n<20$} & 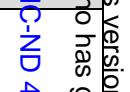 \\
\hline $\begin{array}{l}\text { East of } \\
\text { England } \\
(n=196) \\
\end{array}$ & $\begin{array}{c}185 \\
(94.4 \%)\end{array}$ & $11(5.6 \%)$ & $195(99.5 \%)$ & $\begin{array}{c}164 \\
(83.7 \%)\end{array}$ & $\begin{array}{c}32 \\
(16.3 \%)\end{array}$ & $14(8.7 \%)$ & $\begin{array}{c}177 \\
(90.3 \%)\end{array}$ & $12(6.1 \%)$ & $19(9.7 \%)$ & $\begin{array}{c}178 \\
(90.8 \%)\end{array}$ & $12(6.1 \%)$ & $164(83.7 \%)$ & $3(1.5 \%)$ & $0(0.0 \%)$ & $\begin{array}{c}192 \\
(98.5 \%)\end{array}$ & $\begin{array}{c}171 \\
(87.2 \%)\end{array}$ & $\begin{array}{c}122 \\
(62.2 \%)\end{array}$ & $42(21.4 \%)$ & 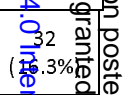 \\
\hline $\begin{array}{l}\text { Greater } \\
\text { London } \\
(n=632)\end{array}$ & $\begin{array}{c}596 \\
(95.1 \%)\end{array}$ & $30(4.8 \%)$ & $623(99.4 \%)$ & $\begin{array}{c}398 \\
(63.5 \%)\end{array}$ & $\begin{array}{c}229 \\
(36.5 \%)\end{array}$ & $36(9.5 \%)$ & $\begin{array}{c}571 \\
(91.1 \%)\end{array}$ & $41(6.5 \%)$ & $94(15.0 \%)$ & $\begin{array}{c}544 \\
(86.8 \%)\end{array}$ & $58(9.3 \%)$ & $540(86.1 \%)$ & $3(0.5 \%)$ & $8(1.3 \%)$ & $\begin{array}{c}611 \\
(98.2 \%)\end{array}$ & $\begin{array}{c}506 \\
(80.7 \%)\end{array}$ & $\begin{array}{c}406 \\
(64.8 \%)\end{array}$ & $\begin{array}{c}154 \\
(24.6 \%)\end{array}$ & 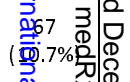 \\
\hline $\begin{array}{r}\text { North East } \\
(n=38)\end{array}$ & $\begin{array}{c}37 \\
(97.4 \%)\end{array}$ & $1(2.6 \%)$ & $37(97.4 \%)$ & $\begin{array}{c}29 \\
(76.3 \%) \\
\end{array}$ & $\begin{array}{c}9 \\
(23.7 \%)\end{array}$ & $3(10.7 \%)$ & $\begin{array}{c}37 \\
(97.4 \%)\end{array}$ & $0(0.0 \%)$ & $4(10.5 \%)$ & $\begin{array}{c}31 \\
(81.6 \%)\end{array}$ & $5(13.2 \%)$ & $32(84.2 \%)$ & $0(0.0 \%)$ & $0(0.0 \%)$ & $\begin{array}{c}38 \\
(100 \%)\end{array}$ & $32(84.2 \%)$ & $\begin{array}{c}26 \\
(68.4 \%)\end{array}$ & $8(21.1 \%)$ & 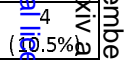 \\
\hline $\begin{array}{r}\text { North West } \\
(n=207)\end{array}$ & $\begin{array}{c}203 \\
(98.5 \%)\end{array}$ & $3(1.5 \%)$ & $204(99.0 \%)$ & $\begin{array}{c}125 \\
(60.7 \%) \\
\end{array}$ & $\begin{array}{c}81 \\
(39.3 \%)\end{array}$ & $6(5.0 \%)$ & $\begin{array}{c}199 \\
(96.6 \%)\end{array}$ & $5(2.4 \%)$ & $18(8.7 \%)$ & $\begin{array}{c}183 \\
(88.8 \%)\end{array}$ & $16(7.8 \%)$ & $174(84.5 \%)$ & $0(0.0 \%)$ & $1(0.5 \%)$ & $\begin{array}{c}205 \\
(99.5 \%) \\
\end{array}$ & $\begin{array}{c}179 \\
(86.9 \%)\end{array}$ & $\begin{array}{c}144 \\
(69.9 \%)\end{array}$ & $40(19.4 \%)$ & 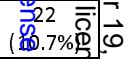 \\
\hline $\begin{array}{r}\text { South East } \\
(n=67)\end{array}$ & $\begin{array}{c}63 \\
(94.0 \%) \\
\end{array}$ & $4(6.0 \%)$ & $67(100 \%)$ & $\begin{array}{c}57 \\
(85.1 \%)\end{array}$ & $\begin{array}{c}10 \\
(14.9 \%)\end{array}$ & $5(9.3 \%)$ & $\begin{array}{c}62 \\
(92.5 \%)\end{array}$ & $5(7.5 \%)$ & $9(13.4 \%)$ & $\begin{array}{c}63 \\
(94.0 \%)\end{array}$ & $3(4.5 \%)$ & $60(89.6 \%)$ & $0(0.0 \%)$ & $0(0.0 \%)$ & $\begin{array}{c}67 \\
(100 \%)\end{array}$ & $55(82.1 \%)$ & $\begin{array}{c}49 \\
(73.1 \%)\end{array}$ & $9(13.4 \%)$ & $\begin{array}{r}9 \% \\
13.4 \% \\
\end{array}$ \\
\hline $\begin{array}{r}\text { South West } \\
(n=77) \\
\end{array}$ & $\begin{array}{c}70 \\
(90.9 \%) \\
\end{array}$ & $7(9.1 \%)$ & $77(100 \%)$ & $\begin{array}{c}54 \\
(70.1 \%) \\
\end{array}$ & $\begin{array}{c}23 \\
(29.9 \%) \\
\end{array}$ & $5(9.4 \%)$ & $\begin{array}{c}75 \\
(97.4 \%) \\
\end{array}$ & $2(2.6 \%)$ & $9(11.7 \%)$ & $\begin{array}{c}67 \\
(87.0 \%) \\
\end{array}$ & $8(10.4 \%)$ & $65(84.4 \%)$ & $1(1.3 \%)$ & $0(0.0 \%)$ & $\begin{array}{c}76 \\
(98.7 \%) \\
\end{array}$ & $66(85.7 \%)$ & $\begin{array}{c}55 \\
(71.4 \%) \\
\end{array}$ & $13(16.9 \%)$ & $\begin{array}{r}9 \\
\left(11.7 \% \frac{2}{n}\right.\end{array}$ \\
\hline $\begin{array}{r}\text { West } \\
\text { Midlands } \\
(\mathrm{n}=7)\end{array}$ & \multicolumn{18}{|c|}{ Not included in tests as $n<20$} & \} \\
\hline $\begin{array}{r}\text { Region } \\
\text { unknown } \\
(n=15)\end{array}$ & \multicolumn{18}{|c|}{ Not included in tests as $n<20$} & \\
\hline Chi2 & \multicolumn{2}{|c|}{$p=0.424$} & $\mathrm{p}=0.611$ & \multicolumn{2}{|c|}{$p<0.001$} & $\mathrm{p}=0.759$ & \multicolumn{2}{|c|}{$p=0.088$} & $p=0.169$ & \multicolumn{2}{|c|}{$\mathrm{p}=0.725$} & $\mathrm{p}=0.862$ & \multicolumn{3}{|c|}{$p=0.346$} & $p=0.182$ & \multirow{2}{*}{\multicolumn{2}{|c|}{$\mathrm{p}=0.278$}} & $\frac{2}{2}$ \\
\hline Postal vs pick u & & & & & & & & & & & & & & & & & & & \\
\hline
\end{tabular}




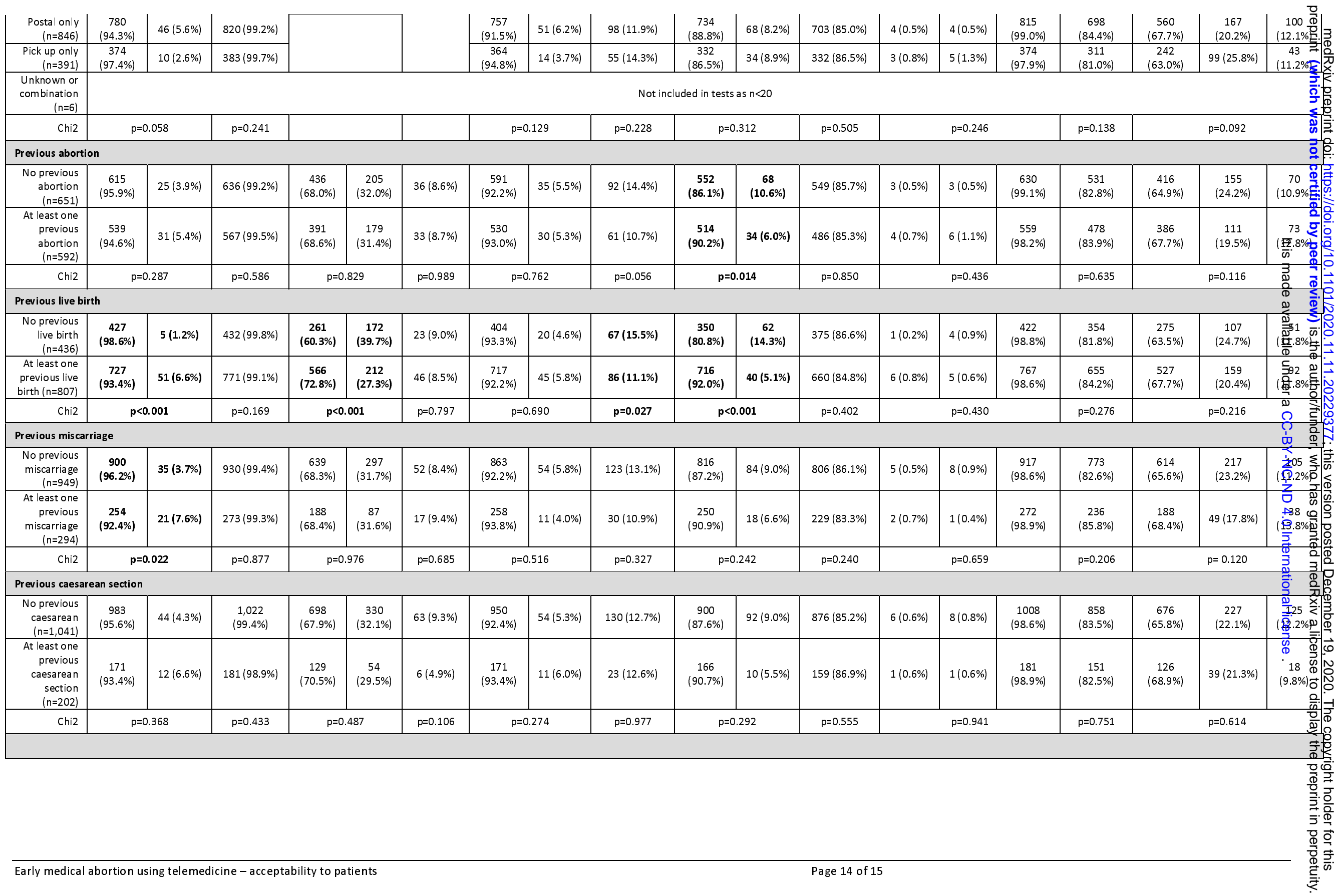


medRxiv preprint doi: https://doi.org/10.1101/2020.11.11.20229377; this version posted December 19 , 2020. The copyright holder for this preprint (which was not certified by peer review) is the author/funder, who has granted medRxiv a license to display the preprint in perpetuity.

It is made available under a CC-BY-NC-ND 4.0 International license.

1. Department of Health \& Social Care (DHSC). Abortion Statistics, England and Wales: 2019. Summary information from the abortion notification forms returned to the Chief Medical Officers of England and Wales. January to December 2019. London; 2020 06/11/2020.

2. National Institute for Health and Care Excellence (NICE). Abortion Care. London; 2019 9/25/2019. Report No.: NG140.

3. Aiken ARA, Guthrie KA, Schellekens M, Trussell J, Gomperts R. Barriers to accessing abortion services and perspectives on using mifepristone and misoprostol at home in Great Britain. Contraception. 2018;97(2):177-83.

4. American College of Obstetricians and Gynecologists (ACOG). Improving Access to Mifepristone for Reproductive Health Indications. Washington DC: ACOG; 2018.

5. Royal College of Obstetricians and Gynaecologists (RCOG), Royal College of Midwives (RCM), Faculty of Sexual \& Reproductive Healthcare (FSRH), British Society of Abortion Care Providers (BSACP). Coronavirus (COVID-19) infection and abortion care. London, UK: Royal College of Obstetricians and Gynaecologists; 2020 31/07/2020. 6. (DHSC) DoHSC. The Abortion Act 1967 - Approval of a Class of Places. London: English Government; 2020. 7. Marie Stopes UK. Marie Stopes UK to start new telemedicine service to deliver early medical abortion care London: Marie Stopes International; 2020 [Available from: www.mariestopes.org.uk/news/marie-stopes-uk-to-startnew-telemedicine-service-to-deliver-early-medical-abortion-care/.

8. Royal College of Obstetricians and Gynaecologists (RCOG). Decision aid for early medical abortion without ultrasound. London: Royal College of Obstetricians and Gynaecologists (RCOG), ; 2020.

9. Department of Health \& Social Care (DHSC). Abortion statistics for England and Wales during the COVID-19 pandemic. In: Department of Health \& Social Care (DHSC), editor. London: UK Government; 2020.

10. Endler M, Lavelanet A, Cleeve A, Ganatra B, Gomperts R, Gemzell-Danielsson K. Telemedicine for medical abortion: a systematic review. BJOG. 2019;126(9):1094-102.

11. Fix L, Seymour JW, Sandhu MV, Melville C, Mazza D, Thompson TA. At-home telemedicine for medical abortion in Australia: a qualitative study of patient experiences and recommendations. BMJ Sex Reprod Health. 2020;46(3):1726.

12. Grindlay K, Lane K, Grossman D. Women's and providers' experiences with medical abortion provided through telemedicine: a qualitative study. Womens Health Issues. 2013;23(2):e117-22.

13. Grossman D, Grindlay K, Buchacker T, Lane K, Blanchard K. Effectiveness and acceptability of medical abortion provided through telemedicine. Obstet Gynecol. 2011;118(2 Pt 1):296-303.

14. Raymond E, Chong E, Winikoff B, Platais I, Mary M, Lotarevich T, et al. TelAbortion: evaluation of a direct to patient telemedicine abortion service in the United States. Contraception. 2019;100(3):173-7. 